\title{
Concept and Application of Limbal Stem Cells
}

\author{
SCHEFFER C. G. TSENG \\ Miami, Florida
}

\begin{abstract}
Summary
Cumulative reported evidence indicates that some fraction of limbal basal epithelial cells are the stem cells for corneal epithelial cell proliferation and differentiation. Limbal epithelium is therefore crucial in maintaining the cell mass of corneal epithelium under normal conditions and plays an important role in corneal epithelial wound healing. Deficiency or absence of limbal stem cells explains well the pathogenesis of several ocular surface disorders characterised by defective conjunctival transdifferentiation or conjunctivalisation of cornea. This paper reviews and updates the basic concept of stem cells, the reported findings of limbal stem cells for corneal epithelium, and their therapeutic applications. Through this review, one hopes to gain a more complete understanding and increase proficiency in treating these diseases.
\end{abstract}

The concept of stem cells (SC) is new to most of us. For example, ophthalmologists who often encounter external diseases with abnormal delayed corneal epithelial wound healing, habitually focus attention on the defect area and ignore the most powerful proliferative source of SC at the limbus. To enhance clinical understanding and proficiency of managing this clinical problem and other related disorders, this paper will review and update the basic concept of SC, the cumulative evidence and new finding of limbal epithelium as SC of corneal epithelium, and their clinical applications.

\section{Basic Concept of Stem Cells:}

Stem cells (SC) are by definition present in all self-renewing tissues. ${ }^{1,2}$ These cells are long- lived, have great potential for clonogenic cell division, and are ultimately responsible for cell replacement and tissue regeneration. Most of our knowledge about stem cells comes from studies on blood cells and some epithelial tissues, e.g. intestinal epithelia, semineferous epithelia, and skin epidermis (see reviews 3,4). Based on cell kinetic studies, all cells in a tissue consisting of a clonogenic cell lineage can be placed into either one of the following two tissue compartments: proliferative or non-proliferative (differentiative) ${ }^{5,6}$ Cells in the proliferative compartment are capable of preceding cell mitosis with DNA synthesis. This compartment includes SC and transient amplifying cells (TAC) that are derived from each SC mitosis and amplify their number by under-

From the Department of Ophthalmology, Bascom Palmer Eye Institute, University of Miami School of Medicine, Miami, Florida.

Correspondence to: Scheffer C. G. Tseng, MD, PhD, Bascom Palmer Eye Institute, P.O. Box 016880, Miami, FL 33101.

This investigation was supported in part by Public Health Service Research Grant \#EY06819 (SCGT), and in part by a Core Grant \#EY02180 Department of Health and Human Services, National Institutes of Health, National Eye Institute, Bethesda, Maryland 20205. 


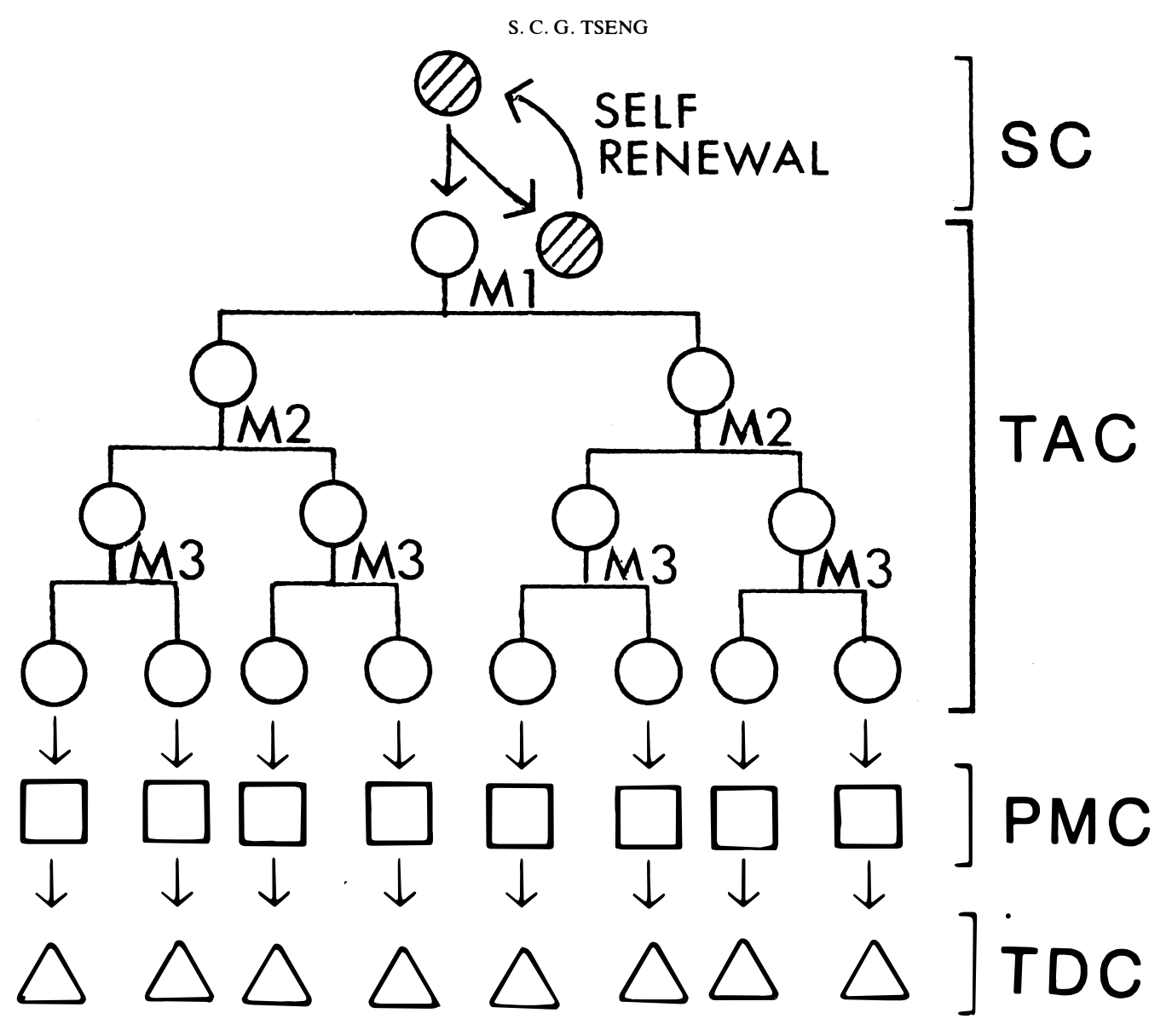

Fig. 1. Schematic drawing of the hierarchy of a defined tissue consisting of stem cell (SC), transient amplifying cell $(T A C)$, post-mitotic cell (PMC), and terminally differentiated cell (TDC). SC is depicted by shaded circle and its population can be recovered via the self-renewal process during an asymmetrical cell division. Three mitotic cycles: M1, M2, and M3 are assigned to TAC. This allows amplification of cell numbers of eight.

going a few rounds of cell division. Cells in the non-proliferative, differentiative compartment are in theory all post-mitotic cells (PMC) that are committed to cellular differentiation. In the latter compartment, cells at different stages of differentiation can be identified during the process of tissue maturation. The ultimate expression of the functional aspect of the tissue is achieved by the terminally-differentiated cells (TDC). All cells except SC have a limited life span and are destined to die. These serial steps of clonogenic cell lineage in a defined tissue are summarised in Figure 1 and Table I, in which one can see an organised cellular hierarchy containing heterogeneous populations of cells that are arranged in the order of
$\mathrm{SC} \rightarrow \mathrm{TAC} \rightarrow \mathrm{PMC} \rightarrow \mathrm{TDC}$. From this schematic diagram, one thus appreciates the fact that the loss of TDC is compensated by the gradual terminal differentiation of the preceding higher hierarchy, PMC, and eventually by the source of cellular proliferation, SC, at the highest rank. Furthermore, to ensure the normal health of the tissue, cellular proliferation and differentiation in a co-ordinated manner at different levels of this hierarchy is important, even indispensable. Physicians who habitually focus attention on cellular dysfunction of the TDC, will gain more insights into the pathogenesis of clinical diseases by analysing the whole cellular hierarchy, particularly by understanding the properties of the SC. 
Table I Cellular components in a defined self-renewing tissue

\begin{tabular}{|c|c|c|c|c|}
\hline & \multicolumn{2}{|c|}{ Proliferative compartment } & \multicolumn{2}{|c|}{ Differentiative compartment } \\
\hline & $\begin{array}{c}\text { Stem } \\
\text { cell }\end{array}$ & $\begin{array}{c}\text { Transient } \\
\text { amplifying } \\
\text { cell }\end{array}$ & $\begin{array}{l}\text { Post- } \\
\text { mitotic } \\
\text { cell }\end{array}$ & $\begin{array}{l}\text { Terminally- } \\
\text { differentiated } \\
\text { cell }\end{array}$ \\
\hline Proliferative capacity & Unlimited & Limited & - & - \\
\hline Mitotic activity & Low & High & - & - \\
\hline Differentiation & + & + & ++ & +++ \\
\hline
\end{tabular}

\section{Properties of Stem Cells:}

Since SC are responsible for ultimate cellular replacement and tissue regeneration, several unique, inherent properties enable SC to accomplish this important task without error.

1. Error-free Proliferation: Ideally, error-free mitosis is absolutely essential since any genetic error at the level of the SC will continuously and permanently pass on to the whole clone of cells, resulting in abnormal differentiation and cellular dysfunction. To minimise any error made in SC mitosis, several protective mechanisms have been developed. First, SC are relatively quiescent during the state of steady growth, and leave the job of active DNA synthesis and cell number amplification to TAC, so that even if an error is made at the TAC level, it will be self-limited because all cells except SC have a limited life span. In cell kinetic terms, SC have a longer cell cycle time, $180 \mathrm{~h} v s .90 \mathrm{~h}$, and a shorter S-phase duration, 2-3 h vs. 9-21 h, as compared to those of TAC in the case of skin epidermis..$^{5-7}$ These data explain (if $\left[{ }^{3} \mathrm{H}\right]$ thymidine is used to label the mitotic cells) why several studies of skin epidermis have shown that SC have a low labelling index or mitotic activity; i.e. one to four per cent for SC as compared to $10-15$ per cent for TAC in skin epidermis. ${ }^{8,9}$ This slow-cycling property of SC indicates a long Go, or resting state. Secondly, Potten et al. ${ }^{10}$ demonstrated that there is asymmetrical DNA segregation during the SC mitosis, suggesting that $\mathrm{SC}$ retains its original genetic message during the mitosis, and allows the new copy to be passed on to TAC. This result also explains why SC utilise a long-lived thymidine pool in DNA synthesis. ${ }^{11}$ Interestingly, in a recent comprehensive mathematical analysis of mouse epidermal cells by Potten and Loeffler et al., ${ }^{12,13}$ it was noted that either of the above two mechanisms, namely, low labelling index and asymmetrical DNA segregation, might operate by itself and successfully explain the data collected from the study of $\left[{ }^{3} \mathrm{H}\right]$ thymidine-labelled clustered cells.

2. Poor differentiation: It has been emphasised that the concept of "stemness" does not include further differentiation as a necessary property. Therefore, it has long been recognised that the cytoplasm of SC appears 'primitive' and contains few, if any, differentiation products. If differentiation is envisioned as a 'reprogramming' of the genome, then the process of differentiation also means 'removal' of cells from the SC population. Therefore, a SC, having responded to a differentiation stimulus, is 'out' of the SC population, and would not be expected to be controlled by the respective control mechanisms of SC proliferation. Two possible mechanisms can explain how a differentiation event is induced. First, a full mitotic cell cycle is needed to produce an asymmetrical cell division into two different daughter cells. One will remain a SC (self-renewal), and the other is destined for cellular differentiation (Fig. 1 , and Reference 10). Secondly, a full cell cycle may not be needed; instead, differentiation stimuli affect SC at the Go state, where most SC are during steady state growth. ${ }^{14,15}$ The affected cells will be 'removed' from the SC population by virtue of the change induced by the differentiation process, and will not enter the SC mitotic cell cycle. 
Both mechanisms might conceivably be operating to induce the differentiation of SC population, and yet it is unclear how SC maintain its 'stemness' or 'poorly-differentiated' status.

3. Anatomical Protection: From the above information, one can appreciate the fact that SC in a defined tissue are usually under extremely careful protection. In the hemopoietic system, SC are stored in bone marrow; in all epithelial tissues, SC are in the basal layer. In addition, SC are thought to be at the crypt position in intestinal epithelia. ${ }^{16}$ Interestingly, in the model of monkey palm epidermis Lavker and Sun ${ }^{9,17}$ found that SC are located at the basal layer of the deep rete ridges where dense melanosomes are found in the presumptive SC located at the bottom of deep rete ridges. The perinuclearly located melanosomes can protect SC from UV damage. An analogous situation can also be found in SC of corneal epithelium at the limbus (see Section IV), where melanosomes are also preferentially distributed, particularly in people with dark skin.

4. Special Regulation: In the steady state, SC are long-lived and are able to balance two conflicting demands: (a) to increase the number of depleted SC, and (b) to increase the rate of differentiation from the depleted SC. The first demand is for selfrenewal; the second is for compensation of cell loss at the lower hierarchy of the tissue. However, under conditions of tissue regeneration, this balance will be difficult to meet. SC population will be depleted or difficult to be recovered due to the need for cellular differentiation. To ensure SC's long-life and compensatory response to tissue demands, a delicate regulatory mechanism must be operating. In the exploration of regulatory mechanisms, great success has been achieved in the hemopoietic system owing to the two major breakthroughs in assaying SC: in vitro using agar culture ${ }^{18}$ and in vivo using spleen colony-forming growth. ${ }^{19}$ A series of investigations into the hemopoietic system have provided evidence that the regulation is operating in the local microenvironment in the bone marrow, in which short-range actions are taking place at cellmatrix and cell-cell levels. ${ }^{20-23}$ In this microenvironment, substrate or attachment factors are able to affect the SC behaviours. In addition, hemopoietic SC are affected by both stimulatory and inhibitory soluble factors (cytokines) from other cells at the normal steady state or regenerating state, respectively. ${ }^{24-27}$. For epithelial tissues, it is not clear how the regulatory mechanisms are operating due to the lack of an appropriate assay for SC clonal growth. More understanding of the regulatory mechanisms will allow us to take advantage of this most powerful source of SC in either self-expansion to maintain the SC population, or in tissue regeneration by stimulating appropriate cellular differentiation.

\section{Identification of Stem Cells:}

To date, all methods for identifying SC in various tissues are indirect. Direct markers for SC have not been established. In the hemopoietic system, SC are observed by means of their resultant single-cell clonal growth in either in vitro agar culture ${ }^{18}$ or in vivo spleen. ${ }^{19}$ Even in such models that are so far best established, one still cannot pinpoint which cell is actually SC and which is not. In epidermis, it is well known that not all basal cells are SC. The heterogeneity of epidermal basal cells have been demonstrated in their $\left[{ }^{3} \mathrm{H}\right]$ thymidine labelling, ${ }^{4,6,28-30}$ EGF receptor distribution, ${ }^{31}$ and responsiveness to tumour promoters. ${ }^{28,32-34}$ As a matter of fact, the use of sectioning parallel to the skin surface has led to the discovery that the epidermis can be regarded as being constituted of adjacent units of cells called epidermal proliferative units (EPU). ${ }^{35-38}$ The EPU is made up of 10-15 layers of cells, but only basal cells proliferate. Among all the 10-11 basal cells in one EPU, the central one is presumed to be SC, which can be identified by prolonged $\left[{ }^{3} \mathrm{H}\right]$ thymidine labelling. ${ }^{39,40}$ EPU structures are found in the skin of all mammalian species so far studied ${ }^{41}$ and recently were also noted in mouse bladder epithelium. ${ }^{42}$ In the specialised epidermis of monkey palm, Lavker and Sun further demonstrated that SC might be located in the basal layer of the non-serrated, deep rete 
ridges (dermal papillae), rather than in that of the serrated, shallow ones. ${ }^{9,17}$ This conclusion was based on showing regional differences in the $\left[{ }^{3} \mathrm{H}\right]$ thymidine labelling as well as in the specific keratin expression on the suprabasal layers. ${ }^{9,17}$

\section{Evidence of Limbal Location of Corneal Epithelial Stem Cells:}

Among all epithelia, corneal epithelium is unique. It is a stratified and highly differentiated epithelium. Like skin epidermis, a high density of desmosomes between cells are noted ${ }^{43}$ but unlike epidermis, corneal epithelium is not keratinised under normal circumstances. ${ }^{44}$ This highly organised structure is primarily responsible for the poor paracellular permeability to non-ionic solutes and water, ${ }^{45}$ and plays an important role in maintaining the smoothness of the optical surface as well as the detergescent state of the corneal stroma. ${ }^{46}$ It has long been recognised that the corneal epithelium is a rapid self-renewing tissue under normal steady state conditions. For example, radiolabels incorporated into the basal cell layers are seen on the the superficial cell layer and disappear within 4 to 6 days. ${ }^{47}$ In the event of central corneal epithelial defects of various sizes in rabbits, the migratory healing rates have been measured in the range of 0.69 to $1.46 \mathrm{~mm}^{2} / \mathrm{hr}$ in vivo, ${ }^{48-50}$ and $0.80 \mathrm{~mm}^{2} / \mathrm{hr}$ in vitro. ${ }^{51}$ It has been a general conception that the basal cells of the corneal epithelium are the proliferative source, based on studies using $\left[{ }^{3} \mathrm{H}\right]$ thymidine labelling ${ }^{52}$ and observations that the central defects are healed by the migration of adjacent cells. ${ }^{53-54}$ As will be described below, evidence has now been gathered that SC of the corneal epithelium are located at the limbal region. This new concept is essential to our understanding of the mechanisms by which corneal epithelial wound healing proceeds during normal and diseased states. We will first review the evidence accumulated to date.

Clinically, we often observe pigmented migration lines from the limbal region after healing of an eccentric corneal epithelial defect; this pigmented line was also observed by Davanger and Evensen in their experiments in guinea pigs, ${ }^{55}$ though without sufficient supporting data, they were the first to speculate the theory that the limbal papillary structure serves as a generative organ for corneal epithelial cells. ${ }^{55}$ With $\left[{ }^{3} \mathrm{H}\right]$ thymidine to label the mitotic basal cells, the mitotic index of the corneal epithelium tends to be higher toward the periphery ${ }^{47,52}$ suggesting that the peripheral corneal basal cells are more active in DNA synthesis. Furthermore, conjunctival intraepithelial neoplasia (CIN), a precancerous condition presumably affecting SC, is predominantly found at the limbal region. ${ }^{56}$ Even such lesions involving the cornea, called corneal intraepithelial neoplasia, were also reported to be contiguous to the adjacent limbus. ${ }^{57}$

\section{Centripetal Movement}

Several studies have shown that the source of cellular proliferation and migration is coming from the peripheral cornea, suggesting that there is centripetal movement responsible for the replacement of cellular loss or attrition noted on the central cornea under both traumatic wounding and the normal atraumatic state.

In the healing of a corneal epithelial defect, the phenomenon of centripetal movement is not surprising to observe because as stated above such healing is accomplished by cellular proliferation and migration of adjacent cells. ${ }^{53,54}$ However, it is of particular interest to point out the observation made by Matsuda et al. ${ }^{50}$ that in rabbits large corneal epithelial defects of $8 \mathrm{~mm}$ in diameter heal faster with a mean healing rate of $0.91 \mathrm{~mm}^{2} / \mathrm{hr}$, than $0.37 \mathrm{~mm}^{2} / \mathrm{hr}$ for smaller defects of $4 \mathrm{~mm}$ in diameter. This result suggests that the peripheral corneal epithelium has a higher proliferative rate. This notion is also supported by a recent report of Ebato et al.,${ }^{58}$ in which they found that the outgrowth area of cultured explants of peripheral cornea is significantly larger than that of the central ones $\left(52.8 \mathrm{~mm}^{2}\right.$ vs. $7.8 \mathrm{~mm}^{2}$ ), and the mitotic activity is also significantly higher (18.8 per cent $v s$. 1.1 per cent). When the central corneal epithelium is repeatedly denuded mechanically, Srinivasan and Eakins $^{59}$ and recently Huang in our laboratory ${ }^{60}$ also noted that the initial healing rate of the second wounding is more rapid than that of the first single denudation. This suggests that the younger peripheral epithelial 
cells have migrated centripetally to the wound edge after the first denudation and respond readily to the second repeated trauma at a faster rate.

In the less traumatic situation, e.g. penetrating keratoplasty or lamellar keratoplasty in which the host central corneal epithelium is substituted by the donor, the centripetal movement of the surrounding host epithelium to replace the donor one is well documented by the elegant work of Kinoshita et al. ${ }^{61}$ They observed a gradual dilution of sex chromatin on the female donor graft by the male recipient over a period of 12 weeks. When one extrapolates their data to the end point of total dilution, it is particularly interesting to note that complete replacement takes about a year. These data are certainly consistent with the clinical observations of centripetal migration of the epithelial dots in penetrating keratoplasty ${ }^{62}$ and the relatively low incidence of epithelial rejection compared to other types of graft rejection one year after penetrating keratoplasty. ${ }^{63}$

Even under the normal atraumatic condition, Buck ${ }^{64}$ also detected centripetal migration of superficial corneal epithelial cells in mice and measured a rate of about $17 \mu \mathrm{m}$ per day. Though there is a species difference, this figure can be well applied to explain the above interpretation and extrapolation in rabbit $^{61}$ and human ${ }^{63}$ corneas that total replacement of the corneal epithelium with a diameter of 10 to $12 \mathrm{~mm}$ takes about a year. Taken together, the above investigations prove the existence of centripetal movement under both traumatic and atraumatic states and indicate that the proliferative source is at the periphery of the cornea. On the same basis, Thoft and Friend ${ }^{65}$ have proposed the $\mathrm{X}, \mathrm{Y}, \mathrm{Z}$ hypothesis to explain how the central corneal epithelial mass is maintained.

The data summarised thus far in the previous reports were still confuisng. The exact anatomical location of SC of the corneal epithelium was unclear until recently when Schermer, Galvin and Sun ${ }^{66}$ first provided indirect evidence suggesting that SC of the corneal epithelium are at the limbus, based on the pattern of expression of a cornea-specific $64 \mathrm{~K}$ keratin. Subsequently, Cotsarelis et al.$^{67}$ also arrived at the same finding based on the result of $\left[{ }^{3} \mathrm{H}\right]$ thymidine incorporation of the corneal/limbal basal cells under stimulation by a tumour promoter. Recently, Lavker et al. $\left({ }^{68}\right.$, and personal communication) noted 30 per cent of mouse limbal basal cells might represent the SC population since they can be labelled by prolonged $\left[{ }^{3} \mathrm{H}\right]$ thymidine incorporation, and thus experimentally as "labelretaining cells". Significantly, these cells are absent in central corneal epithelium. Based on these findings, together with the known centripetal migration of corneal epithelial cells, Schermer et al. ${ }^{66}$ further suggested that corneal basal cells represent TAC and suprabasal cells correspond to PMC and TDC.

\section{Anatomy of Limbus:}

Anatomically, the limbus acts as a junctional zone to separate cornea from conjunctiva, two distinctively different tissues. All three together make up the ocular surface epithelia. Histologically, limbal epithelium is also unique; it consists of more than 10 cell layers and is the thickest among the three as compared to 1-2 cell layers for the conjunctival epithelium and 4-6 cell layers for the corneal epithelium. Phenotypic expression of the limbal epithelium has been regarded as intermediate between corneal and conjunctival epithelium (i.e. rabbits). For example, in wound healing of a total corneal epithelial defect by limbal epithelium, the resultant epithelium is morphologically similar to that of cornea but its glycogen content and protein profile are intermediate between that of corneal and conjunctival epithelium. ${ }^{69,70}$ Interestingly, ultrastructural analysis of human limbus suggests that there may be crypt openings for goblet cells, ${ }^{71}$ a unique feature of conjunctival epithelium. It is still unknown whether this junctional epithelium can serve as the SC source for both corneal and conjunctival epithelia. In humans, a regional specialisation of the epithelial structure had been identified at the limbus and was called 'Limbal palisades of Vogt'. ${ }^{72,73}$ As stated earlier, this structure was first speculated by Davanger and Evensen ${ }^{55}$ to be the generative organ for corneal epithelial cells. Like the deep rete ridges of monkey palmar epidermis, ${ }^{9,17}$ the limbal palisades of Vogt are also 
rich in melanin content,${ }^{55}$ particularly in darkskinned people. The basal cells of this structure, some of which are the presumed SC, are tightly attached to the underlying basement membrane and have a rich network of blood supply. ${ }^{74}$ More understanding of this region, particularly its microenvironment, will shed some light on the regulatory mechanism of SC at the limbus.

\section{Aplasia of Limbal Stem Cells as a Cause of Abnormal Wound Healing}

As discussed above, corneal epithelium can be regenerated efficiently by limbal epithelium. In the absence, or aplasia, of limbal epithelium (i.e. defect extending beyond the
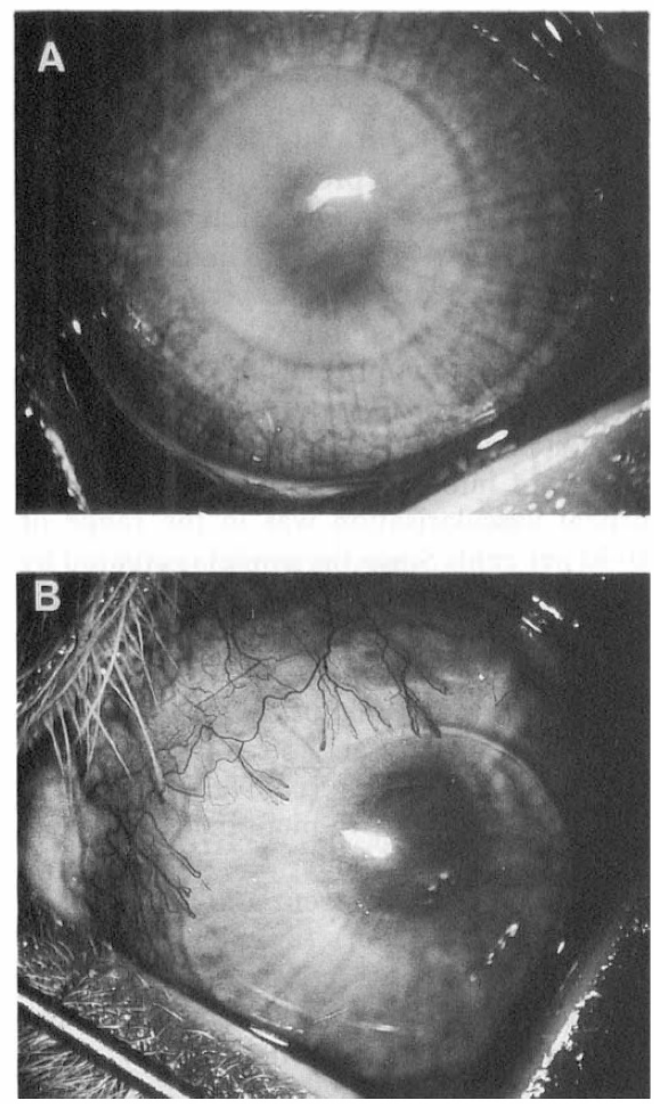

Fig. 2. External photograph of a normal control cornea $(A)$ and an experimental cornea of which the limbal epithelium had been surgically removed $(B)$. Both corneas have received two consecutive central $7.5 \mathrm{~mm}$ epithelial debridements, that are outlined by arrows. Note the occurrence of vascularisation in experimental cornea (B) after complete healing. limbus), healing becomes less efficient ${ }^{69,75}$ and is characterised by recurrent erosion. ${ }^{76}$ Experimentally, such abnormal wound healing has been analysed in various ways, which can be further categorised as follows:

When the limbal epithelium was surgically removed from the rabbit eye in a ring fashion, Huang $^{60}$ in my laboratory noted that this defect was healed rapidly by adjacent epithelial cells without any erosion. In a total of 11 eyes, 36 per cent developed peripheral corneal neovascularisation during an observation period of six months. To examine if the proliferative capacity of the epithelial cells at the limbal region is functionally intact, a central $7.5 \mathrm{~mm}$ corneal epithelial defect was created in this experimental group and compared with that created in another 11 normal controls. Delayed wound healing and moderate corneal neovascularisation developed in 45 per cent and 64 per cent, respectively, of the experimental corneas and none in controls $(\mathrm{p}<0.05)$. A second $7.5 \mathrm{~mm}$ defect was then induced 3 weeks later. Markedly delayed healing with recurrent erosion and increased neovascularisation was noted in 90 per cent and 64 per cent, respectively, of the experimental corneas and none in controls $(\mathrm{p}<0.01$ and $\mathrm{p}<0.05$ respectively). Accompanying the above changes, the experimental corneas exhibited centripetal movement of goblet cells. In contrast, no goblet cells were noted on the control corneas. One such example is illustrated in Figure 2, showing the difference in their external appearance. This result strongly indicates that limbal epithelium possesses a very high proliferative capacity for generating cornea-like epithelium. In addition, limbal epithelium seems to be able to exert prohibitive growth pressure against conjunctival epithelial invasion under normal circumstances. A deficiency of limbal SC, in this case by surgical removal, induces early appearance of defective conjunctival transdifferentiation or conjunctivalisation of cornea (also see below).

When a total corneal epithelial defect is created to include limbal epithelium, the denuded surface can only be healed by the surrounding conjunctival epithelium. During the healing process, the fate of the migrating conjunctival epithelium on the denuded cor- 
neal surface will be determined by the presence or absence of corneal vascularisation. In its absence, the conjunctiva-like epithelium will undergo several stages of morphological transformation into a cornea-like epithelium with the loss of goblet cells, ${ }^{77-79}$ a process now termed conjunctival transdifferentiation. This process has been the subject of intensive investigation by several researchers, including Thoft and Friend et al. ${ }^{69,70,78,80-83}$ Liu et al. ${ }^{84}$ Harris et al.,$^{85}$ and ourselves, ${ }^{79,86-90}$ because it suggests that corneal epithelium can be regenerated by a conjunctival source. Nevertheless, the resultant morphological transformation is just cornea-like, and not the genuine corneal phenotype. This notion is supported by the results of previous investigations in studies of glycolytic enzyme and glycogen content,${ }^{80}$ normal tensile strength ${ }^{81}$ keratin profile,${ }^{70}$ epithelial protein profile,${ }^{85}$ and paracellular permeability. ${ }^{89}$ These investigations indicate that the morphological transformation is accompanied by incomplete biochemical or physiological transformation. One can thus speculate that conjunctival transdifferentiation is analogous to the squamous metaplasia of mucosal epithelia under systemic vitamin A deficiency, a process also characterised by loss of goblet cells and increased cellular stratification at an early stage and keratinisation at a later stage. ${ }^{44,91}$ To prove this notion, we have previously demonstrated that conjunctival transdifferentiation is not a permanent, stable phenotypic expression; instead, it can.be modulated by changing the local supply of vitamin A with or without inducing corneal vascularisation. ${ }^{86-90}$ The results of these experiments are summarised in Figure 3.

All the above investigations ${ }^{69,70,78-90}$ in the study of conjunctival transdifferentiation, however, did not rule out the possibility that the initial chemical debridement with n-heptanol ${ }^{92}$ in creating the experimental model had not removed the entire limbal epithelium, nor had they excluded the likelihood that limbal or conjunctival epithelum might contain SC that have a bipotent capacity for both corneal and conjunctival epithelial differentiation. For the former possibility, incomplete removal of limbal epithelium can result in a mixed expression on both corneal and con- junctival lineages on the denuded corneal surface, which certainly can explain the aforementioned incomplete transformation and modulability by local vitamin A levels.

In contrast, if corneal vascularisation is present during the healing period ${ }^{77,79,93}$ or introduced afterwards, ${ }^{82,84,89}$ the process of conjunctival transdifferentiation is either inhibited ${ }^{77,79,82}$ or reversed, ${ }^{84,89}$ as evidenced by the persistence of goblet cells on the corneal surface. One may thus conclude that the resultant epithelial phenotype can be determined by the vascular status of the cornea (also see Fig. 3). Based on our recent finding that the incidence of corneal vascularisation increases significantly more on the corneas without limbal epithelium than their controls (the first type of abnormal wound healing shown in Fig. 2 and Reference 60), one may wonder if the occurrence of corneal neovascularisation in the latter healing process of the defective conjunctival transdifferentiation model is due to the complete removal of limbal SC. We have reviewed our past experience in this model using the n-heptanol chemical debridement $^{79,86,90}$ and found that the occurrence of these two corneal types was haphazard, unpredictable, and possibly related to the severity of injury. The over-all incidence of corneal vascularisation was in the range of 20-30 per cent. Since the model is created by chemical debridement to remove epithelium, we speculated that the difference in the above two types of healing might represent the extent of removal of limbal SC..$^{90}$ To examine this hypothesis, a total of 50 rabbit eyes have received a surgical ring removal of limbus in addition to the above-mentioned chemical debridement; we found that corneal neovascularisation was present and persistent in 48 eyes (96 per cent) (unpublished observations and also see Section VIII).

To date, we can tentatively summarise that conjunctival transdifferentiation may result from incomplete removal of limbal SC. The resultant epithelium manifests both corneal and conjunctival characteristics and is fully modulable by corneal vascularisation. However, complete removal of limbal SC results in the defect of conjunctival transdifferentiation in which conjunctivalisation of the cornea is 


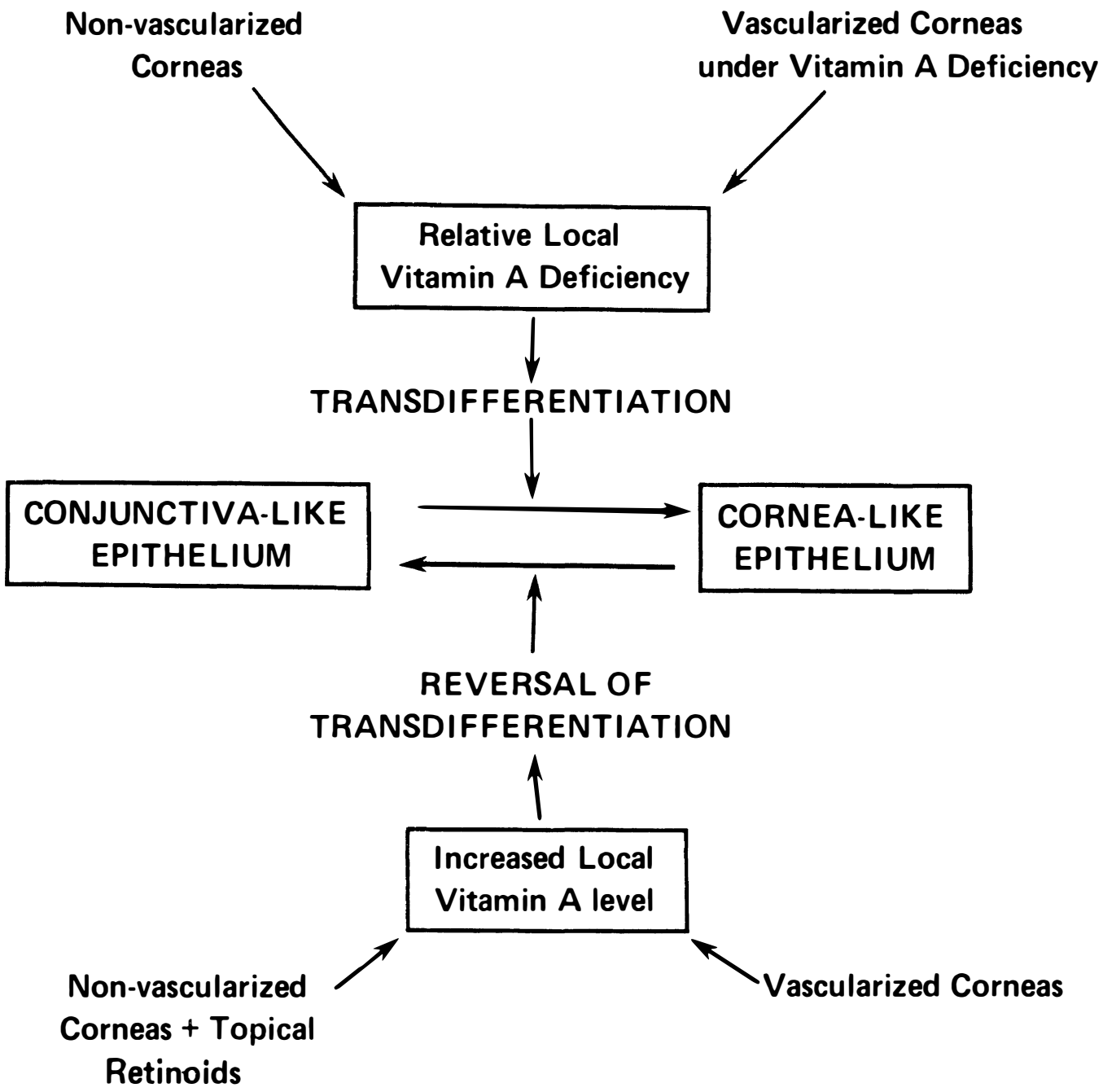

Fig. 3. Summarv of the hypothesis explaining the modulating mechanism of conjunctival transdifferentiation. The process of transdifferentiation is thought to result from relative local vitamin $A$ deficiency, which has been iested experimentally by either examining non-vascularised corneas ${ }^{79}$ or by inducing vitamin $A$ deficiency in vascularised ones. ${ }^{87}$ On the other hand, the reversal of transdifferentiation occurs as a result of increased local vitamin A level to the corneas, either by applying topical retinoids to non-vascularised corneas ${ }^{86,88}$ or by examining vascularised ones. ${ }^{79}$ (With permission from Invest Ophthalmol Vis Sci, Reference 86.)

invariably present together with vascularisation.

\section{Clinical Implications:}

Clinically, the conjunctival transdifferentiation defect or conjunctivalisation of cornea described above can be found in several ocular surface disorders (Table II). This was generated by using impression cytology ${ }^{94}$ on corneal surface in a survey of clinical patients. ${ }^{95}$ Histopathologically, these diseases are all featured by the overgrowth or invasion of conjunctival epithelium, accompanied by neovascularisation, disruption of basement membrane, and inflammatory cell infiltrates. Impression cytology demonstrates that all have goblet cells and conjunctival epithelial cells on the involved corneal surface. ${ }^{95}$ In the case of pterygium and some cases of StevensJohnson syndrome, a prominent fibrous 
Table II Ocular surface disorders characterised by the absence (aplasia) of limbal stem cells

1. Hereditary: Aniridia (bilateral)

Keratitis associated with multiple endocrine deficiency (bilateral)

2. Acquired:

(a) Diffuse: Stevens-Johnson syndrome (bilateral)

Chemical injuries (unilateral/bilateral)

Contact lens-induced keratopathy (unilateral/bilateral)

(b) Focal: Pterygium

The table is generated from the survey of clinical patients using impression cytology. ${ }^{94}$ The absence or aplasia of limbal stem cells is determined by the existence of oconjunctival goblet cells on the corneal surface (unpublished data, also see text).

ingrowth is also present. Such tissue alterations are the basis of compromised corneal functions and are consistent with the experimental data. Patients usually suffer from recurrent erosion and decreased vision as a result of irregular optical surface, weak tensile strength, ${ }^{81}$ decreased glycogen content,${ }^{80}$ and incompetent barrier function. ${ }^{89}$ In chemical injuries and some cases of Stevens-Johnson syndrome, the conjunctival transdifferentiation defect develops due to the destruction of corneal and limbal epithelia, a situation similar to the above experimental model. In the evaluation of the clinical severity of chemical injuries, it is noteworthy that corneal epithelial defect and limbal ischaemia, indicative of the extent of limbal destruction, are the two important prognostic factors used by Hughes in his grading of clinical severity and prognosis. ${ }^{96,97}$ In aniridia, there might be a deficiency in the development or maintenance of limbal SC that is associated with the absence of iris and abnormality found in the angle. ${ }^{98-100}$ The contact lens-induced keratopathy with conjunctival transdifferentiation defect is a rare occurrence compared to other types of ocular complications. The fact that it is associated with soft lens suggests that limbal SC might preferentially be damaged by such insults as hypoxia, mechanical irritations, or toxicity from lens care solution. The above diseases may all represent the absence or deficiency of limbal SC in a diffuse or focal manner. Their occurrence may be hereditary or acquired and can be unilateral or bilateral (Table II).

One should also recognise that a deficiency of limbal SC may not be limited to those listed in Table II. For example, alteration of the microenvironment with respect to the cell-cell and/or cell-matrix interactions can result in an altered regulatory mechanism of limbal SC function leading to abnormal epithelial phenotypes. It is therefore conceivable that the persistent epithelial defect secondary to neurotrophic keratopathy may be one such example of hypofunction of limbal SC. Conjunctival or corneal intraepithelial neoplasia may represent the dysplasia of limbal SC.

\section{Therapeutic Applications:}

Based on the above concept, several therapeutic applications can be outlined. For those clinical disorders characterised by deficiency or hypofunction of limbal SC, modulations of the microenvironment by changing the insoluble substrate factors or the stimulatory and inhibitory soluble factors to limbal SC, may conceivably expand the SC population. Further amplification of TAC by appropriate mitogenic factors can then increase the overall proliferative compartment. Appropriate stimulation to induce orderly cellular differentiation can enhance tissue maturation and functional restoration. To date, several growth factors including epidermal growth factor (EGF) $)^{101-105}$ and fibronectin ${ }^{106-108}$ have been used to treat, experimentally and clinically, persistent corneal epithelial defects. These investigations represent important trials of stimulation of wound healing and cell attachment by mitogens.

For those ocular surface disorders characterised by the absence or aplasia of limbal SC, replacement or transplantation of SC seems to be the logical solution for ocular surface reconstruction. This is particularly feasible for those diseases which have unilateral involvement (Table II). When the limbus is focally involved in one eye, an autograft can be 


\section{TOTAL REMOVAL OF LIMBAL EPITHELIUM}

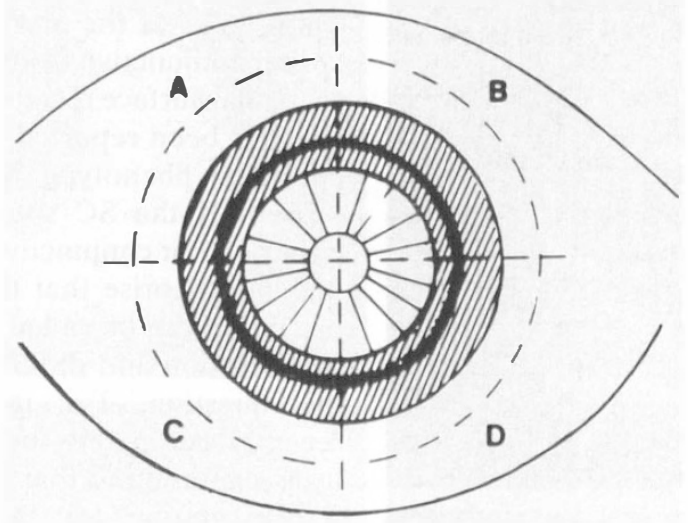

\section{LIMBAL TRANSPLANTATION}

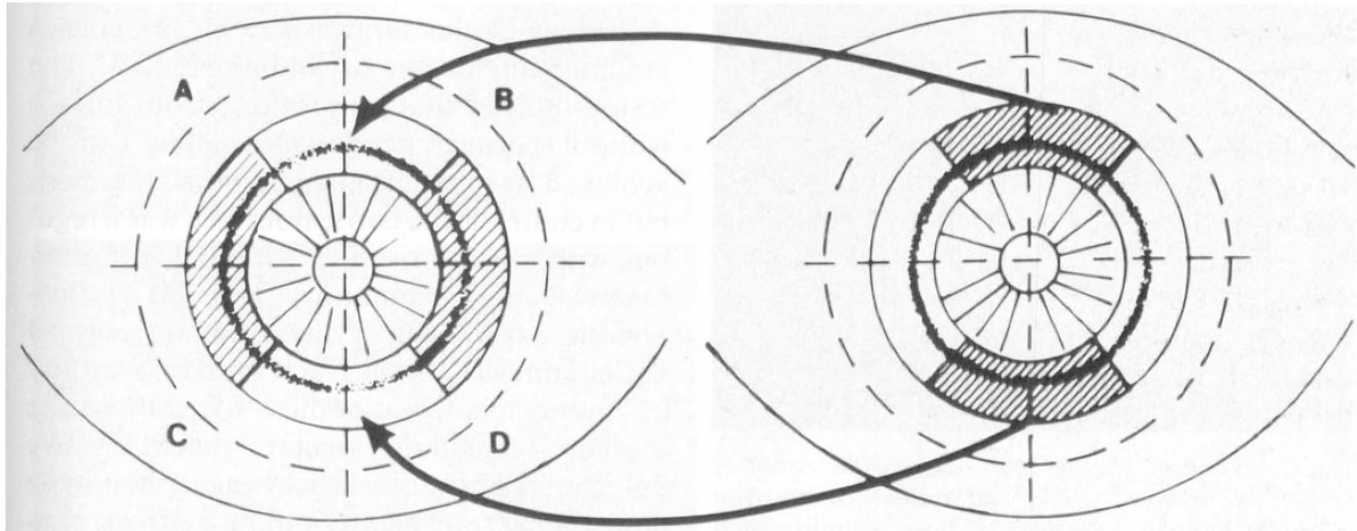

\section{CONJUNCTIVAL TRANSPLANTATION}

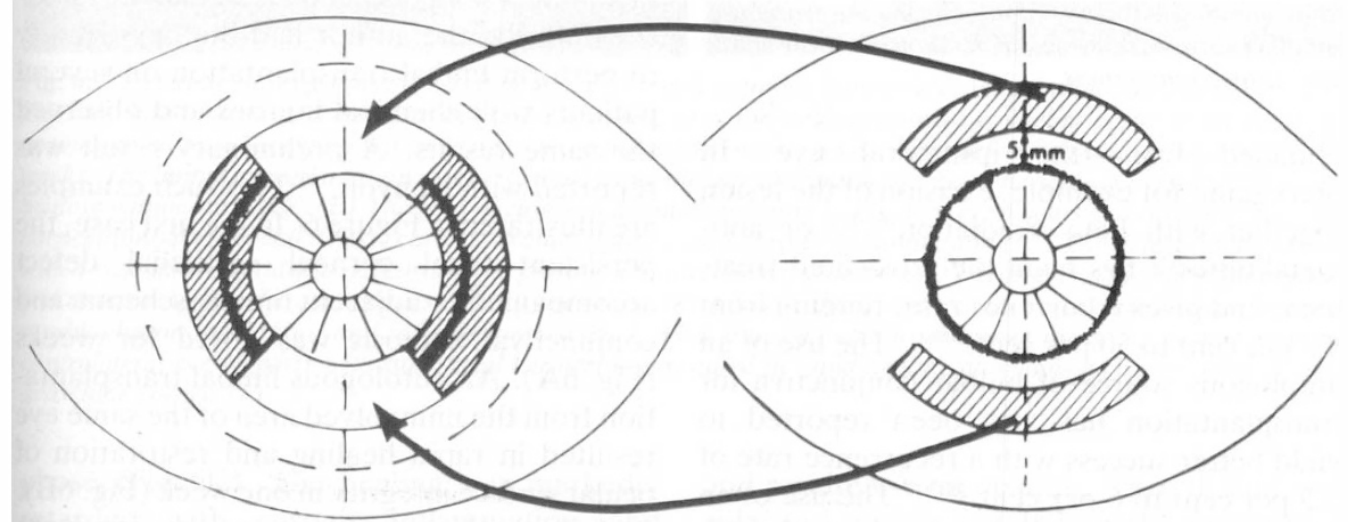

Fig. 4. Schematic drawings showing the total removal of corneal and limbal epithelia (upper panel, shaded area) and the methods of autologous transplantation from contralateral limbus (middle panel) and bulbar conjunctiva (lower panel). 

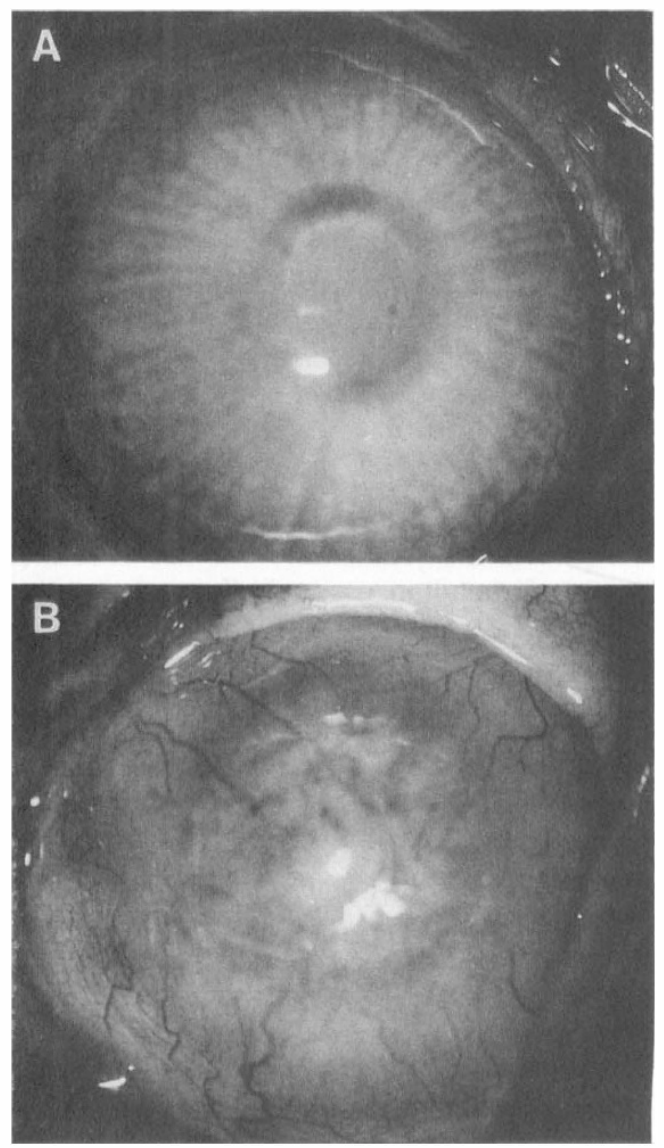

Fig. 5. External photographs showing the result of iimbal transplantation (A) and bulbar conjunctival transplantation $(B)$. One month prior to transplantation, both corneas received total removal of corneal and limbal epithelia using a combination of $N$-heptanol ireatment ${ }^{2}$ and surgical dissection (also see Fig. 4). Photographs were taken one month after the procedure. Vote the difference in vascularisation, corneal clarity and surface smoothness.

obtained from the ipsilateral eye. In pterygium, for example, excision of the lesion together with beta irradiation ${ }^{109-111}$ or antimetabolites $^{112}$ has been the advocated treatment and gives recurrence rates ranging from 4.3 per cent to 50 per cent.$^{109-111}$ The use of an autologous source of bulbar conjunctiva for transplantation has also been reported to yield better success with a recurrence rate of 5.3 per cent to 6 per cent. ${ }^{113.114}$ The use of an autograft including limbus by Rivaud et al. showed a recurrence rate of 3 per cent. ${ }^{115}$ No prospective study is available to compare these different approaches. For unilateral, moderate or severe chemical injuries, Thoft ${ }^{116,117}$ was the first to pioneer the use of bulbar conjunctiva from the contralateral eye for ocular surface reconstruction. Clinical success has been reported ${ }^{116,117}$ but the resultant epithelial phenotype has not been characterised. If the SC source is equivalent for either bulbar conjunctival or limbal epithelia, one can theorise that there are SC in either place that can be called for corneal epithelial proliferation and differentiation. To explore this question, Tsai in my laboratory has recently compared the efficiency of limbal transplantation to that of bulbar conjunctival transplantation for corneal surface reconstruction in rabbit eyes with unilateral total removal of corneal and limbal epithelia, which was using a combination of chemical debridement plus surgical scraping for cornea and ring dissection of limbus (Fig. 4). The results indicate that a smooth, lustrous surface without corneal neovascularisation can be achieved by limbal transplantation (Fig. 5A), but in contrast, the corneal surface was irregular with vascularisation after bulbar conjunctival transplantation (Fig. 5B). Phenotypic expression of the resultant corneal epithelium was also characterised by a battery of monoclonal antibodies to cell-specific markers including ocular mucin. ${ }^{118} \mathrm{We}$ detected restoration of the corneal phenotype after limbal transplantation; in contrast, conjunctivalisation of the cornea was observed after bulbar conjunctival transplantation (Tsai and Tseng, unpublished result).

Clinically, the author had the opportunity to perform limbal transplantation on several patients with chemical injuries and observed the same results. A preliminary result was reported with Kenyon. ${ }^{119}$ Two such examples are illustrated in Figure 6. In the first case, the persistent focal corneal epithelial defect accompanied by adjacent limbal ischemia and conjunctival necrosis was noted for weeks (Fig. 6A). An autologous limbal transplantation from the uninvolved area of the same eye resulted in rapid healing and restoration of ocular surface integrity in one week (Fig. 6B). In the second case of battery acid injury, more severe and diffuse damage to the entire corneal/limbal region was noted in the acute 

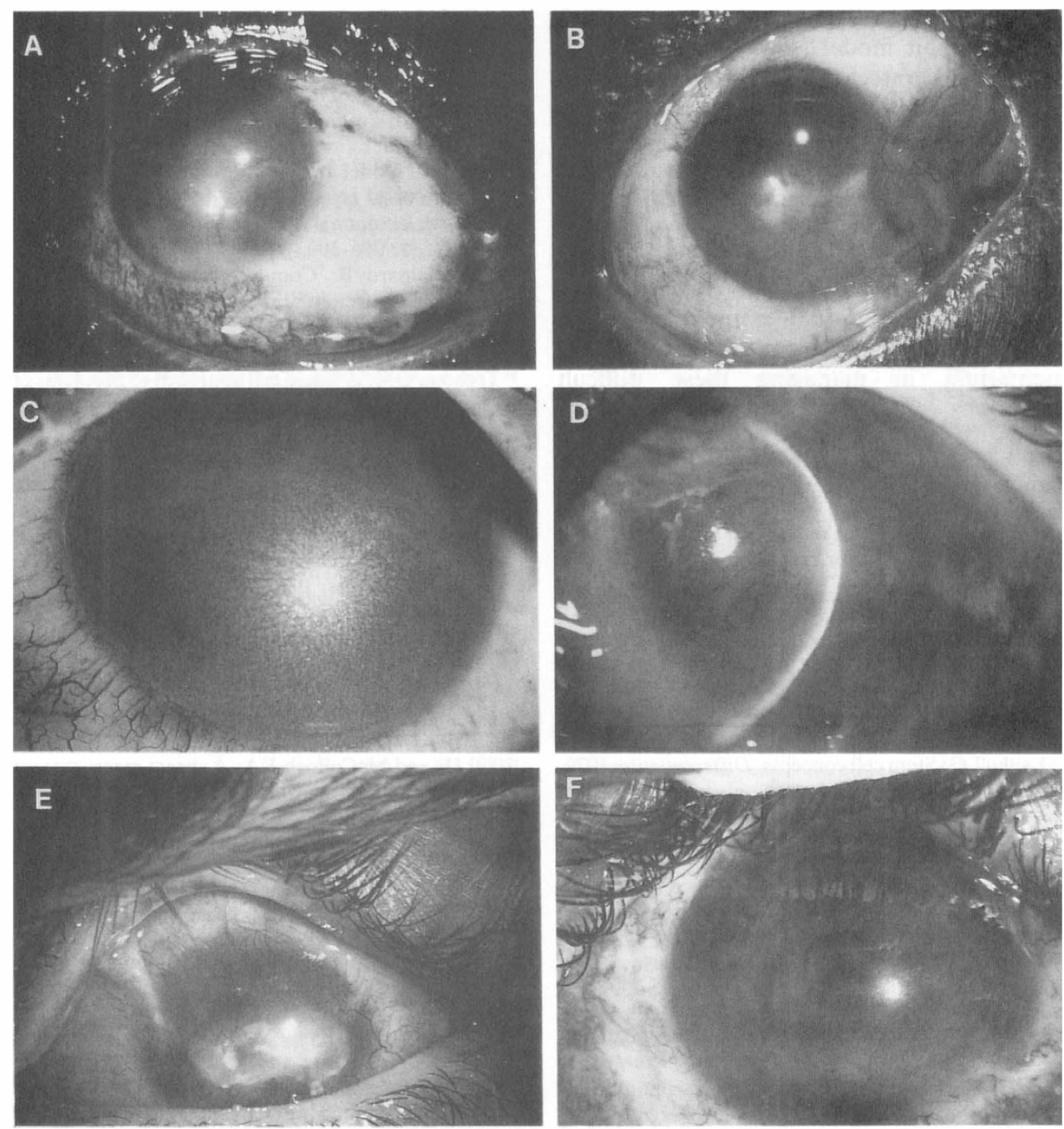

Fig. 6. External photographs of two clinical patients with chemical injuries receiving limbal transplantation. The first case had battery acid injury to both eyes resulting in a non-healing corneal epithelial defect in the right eye accompanied by adjacent limbal ischaemia and conjunctival necrosis $(A)$. This defect had been persistent for five weeks. The limbal transplantation was performed using the supratemporal source of the same eye resulting in a total healing within one week. $(B)$ The second case had an alkaline injury to his right eye 6 years ago resulting in a total corneal/limbal epithelial defect, corneal stromal opacity, and chronic inflammation $(C)$. The defect finally healed with a vascularised and scarred cornea, the photograph was taken a year later $(D)$. However, chronic inflammation and recurrent corneal erosion persisted for a few years. This finally resulted in a dense corneal scar and conjunctival symblepharon in superior and inferior fornix $(E)$. Limbal transplantation performed using the source from the contralateral eye together with superficial keratectomy resulted in rapid healing as well as a clearer, smooth, and avascular cornea $(F)$.

phase (Fig. 6C). The healing was markedly retarded with chronic inflammation and recurrent erosion for a period of 8 months (Fig. 6D). This healing was finally completed and resulted in an opaque, scarred, and vascularised cornea together with conjunctival cicatricial changes (Fig. 6E). Limbal transplantation from the contralateral eye in a 
similar fashion to that described in an experimental rabbit model (Fig. 4) together with superficial keratectomy has facilitated recovery of the smoothness and clarity of the cornea (Fig. 6F).

In summary, more therapeutic implications can be drawn, if more knowledge of the regulatory mechanisms of SC can be obtained. This will not only enhance our understanding of the pathogenesis of various clinical diseases featured by abnormal corneal epithelial wound healing, but also our therapeutic armamentarium in managing these difficult conditions.

The author thanks Lawrence W. Hirst, MD, for encouraging him to explore the disease of aniridia, Tung-Tien Sun, PhD and Robert W. Lavker, PhD for inspirational teaching on the subject of stem cells, and Mrs. Marietta Turner for preparing this manuscript.

\section{References}

${ }^{1}$ Cairnie AB, Lala PK, Osmond DG (eds.): Stem Cells of Renewing Cell Populations. New York, Academic Press, 1976.

${ }^{2}$ Leblond CP: The life history of cells in renewing systems. Am, J Anat 1981, 160: 114-158.

${ }^{3}$ Lajtha LG: Stem cell concepts. Differentiation 1979 , 14: 23-34.

${ }^{4}$ Potten CS: Epithelial proliferative subpopulations: In: Stem Cells and Tissue Homeostasis: Lord BI, Potten CS, Cole RJ (eds.). Cambridge: Cambridge University Press, 1978; p. 317.

${ }^{5}$ Clausen OPF, Aarnaes E, Kirkhus B, Pedersen S, Thorud E, Bolund L: Subpopulations of slowly cycling cells in S and G2 phase in mouse epidermis. Cell Tissue Kinet 1984, 17: 351-65.

6 Jensen PKA, Pedersen S, Bolund L: Basal-cell subpopulations and cell-cycle kinetics in human epidermal explant cultures. Cell Tissue Kinet 1985, 18: 201-15.

${ }^{7}$ Potten CS, Wichmann HE, Loeffler M, Dobek K, Major D: Evidence for discrete cell kinetic subpopulations in mouse epidermis based on mathematical analysis. Cell Tissue Kinet 1982, 15: 30529.

8 Potten CS, Wichmann HE, Dobek K, Birch J, Codd TM, Horrocks L, Pedrick M, Tickle SP: Cell kinetic studies in the epidermis of mouse. III. The percent labelled mitosis (PLM) technique. Cell Tissue Kinet 1985, 18: 59-70.

${ }^{9}$ Lavker RM and Sun TT: Epidermal stem cells. $J$ Invest Dermatol 1983, 81 (1 Suppl): 121s-27s.

${ }^{10}$ Potten CS, Hume WJ, Reid P, Cairns J: The segregation of DNA in epithelial stem cells. Cell 1978, 15: 899-906.

${ }^{11}$ Hume WJ and Potten CS: A long-lived thymidine pool in epithelial stem cells. Cell Tissue Kinet 1982, 15: 49-58.

${ }^{12}$ Potten CS and Loeffler M: Epidermal cell prolifera- tion. I. Changes with time in the proportion of isolated, paired and clustered labelled cells in sheets of murine epidermis. Virchows Arch [B] 1987, 53: 279-285.

${ }^{13}$ Loeffler M, Potten CS, Wichmann HE: Epidermal cell proliferation. II. A comprehensive mathematical model of cell proliferation and migration in the basal layer predicts some unusual properties of epidermal stem cells. Virchows Arch [B] 1987, 53: 286-300.

${ }^{14}$ Nadal-Ginard B: Commitment, fusion and biochemical differentiation of a myogenic cell line in the absence of DNA synthesis. Cell 1978, 15: 855 64.

${ }^{15}$ Technau GM: A single cell approach to problems of cell lineage and commitment during embryogenesis of Drosophila melanogaster. Development 1987, 100: 1-12.

${ }^{16}$ LeBlond CP and Cheng $\mathrm{H}$ : Identification of stem cells in the small intestine of the mouse. In: Stem Cells of Renewing Cell Populations. Cairnie AB, Lala PK and Osmond DG (eds.). New York: Academic Press, 1976; pp. 7-31.

${ }^{17}$ Lavker RM and Sun TT: Heterogeneity in epidermal basal keratinocytes: Morphological and functional correlations. Science 1982, 215: 1239-41.

${ }_{18}$ Pluznik DH and Sachs L: The cloning of normal 'mast' cells in tissue culture. J Cell comp physiol 1965, 66: 319-24.

${ }^{19}$ Till JE and McCulloch EA: A direct measurement of the radiation sensitivity of normal mouse bone marrow cells. Radiat Res 1961, 14: 213-22.

${ }^{20}$ Croizat H, Frindel E, Tubiana M: Proliferative activity of the stem cells in the bone-marrow of mice after single and multiple irradiations. (Total-or partial-body exposure). Int J Radiat Biol 1970, 18: 347-58.

${ }^{21}$ Rencricca NJ, Rizzoli V, Howard D, Duffy P, Stohlman F Jr: Stem cell migration and proliferation during severe anemia. Blood 1970, 36: 764-71.

22 Patt HM and Maloney MA: Relationship of bone marrow cellularity and proliferative activity: A local regulatory mechanism. Cell Tissue Kinet 1972, 5: 303-9.

${ }^{23}$ Gidali J and Lajtha LG: Regulation of haemopoietic stem cell turnover in partially irradiated mice. Cell Tissue Kinet 1972, 5: 147.

${ }^{24}$ Lord BI, Mori KJ, Wright EG, Lajtha LG: Inhibitor of stem cell proliferation in normal bone marrow. Br J Haematol 1976, 34: 441-5.

${ }^{25}$ Frindel E, Croizat H, Vassort F: Stimulating factors liberated by treated bone marrow: In vitro effect on CFU Kinetics. Exp Haematol 1976, 4: 56-61.

${ }^{26}$ Frindel $\mathrm{E}$ and Guigon M: Inhibition of CFU entry into cycle by a bone marrow extract. Exp Hematol 1977, 5: $74-6$.

${ }^{27}$ Lord BI, Mori KJ, Wright EG: A stimulator of stem cell proliferation in regenerating bone marrow. Biomedicine 1977, 27: 223-6.

${ }^{28}$ Morris RJ, Fischer SM, Slaga TJ: Evidence that the centrally and peripherally located cells in the murine epidermal proliferative unit are two dis- 
tinct cell populations. J Invest Dermatol 1985, 84: 277-81.

${ }^{29}$ Milstone LM and LaVigne JF: Heterogeneity of basal keratinocytes: Non-random distribution of thymidine-labelled basal cells in confluent cultures is not a technical artifact. $J$ Invest Dermatol 1985, 84: 504-7.

${ }^{30}$ Bickenbach JR, McCutecheon J, MacKenzie IC: Rate of loss of tritiated thymidine label in basal cells in mouse epithelial tissues. Cell Tissue Kinet 1986, 19: 325-33.

${ }^{31}$ Green MR and Couchman JR: Differences in human skin between the epidermal growth factor receptor distribution detected by EGF binding and monoclonal antibody recognition. J Invest Dermatol 1985, 85: 239-45.

32 Klein-Szanto AJP and Slaga TJ: Numerical variation of dark cells in normal and chemically induced hyperplastic epidermis with age of animal and efficiency of tumor promoter. Cancer Res 1981, 41: 4437-40.

${ }^{33}$ Morris RJ, Fischer SM, Slaga TJ: Evidence that a slowly cycling subpopulation of adult murine epidermal cells retains carcinogen. Cancer Res 1986 , 46: 3061-6.

${ }^{34}$ Hesterberg TW, Maness SC, Iglehart JD, Sanchez JH, Boreiko CJ: Subpopulations of human bronchial epithelial cells in culture respond heterogeneously to 12-0-tetradecanoylphorbol-13-acetate (TPA) and other modulators of differentiation. Carcinogenesis 1987, 8: 1511-15.

${ }^{35}$ MacKenzie IC: Ordered structure of the stratum corneum of mammalian skin. Nature 1969, 222: 881-2.

${ }^{36}$ MacKenzie IC: Relationship between mitosis and ordered structure of the stratum corneum in mouse epidermis. Nature 1970, 226: 653-5.

37 Allen TD and Potten CS: Fine-structural identification and organization of the epidermal proliferative unit. J Cell Sci 1974, 15: 291-319.

${ }^{38}$ Potten CS: The epidermal proliferative unit: The possible role of the central basal cell. Cell Tissue Kinet 1974, 7: 77-88.

${ }^{39}$ Bickenbach JR: Identification and behavior of label-retaining cells in oral mucosa and skin. $J$ Dent Res 1981, (spec. no. c): 1611-20.

${ }^{40}$ Bickenbach JR and MacKenzie IC: Identification and localization of label-retaining cells in hamster epithelia. J Invest Dermatol 1984, 82: 618-22.

${ }^{41}$ Potten CS: Cell replacement in epidermis (keratopoiesis) via discrete units of proliferation. Int Rev Cytol 1981, 69: 271-318.

42 Thiebaut F, Reitan JB, Feren K, Rigaut JP, Reith A: An epidermal proliferative unit-like structure in the epithelium of mouse bladder observed by backscattered electron imaging. Cell Tissue Res 1986, 246: 1-6.

${ }^{43}$ Billingham RE and Medawar PB: A note on the specificity of corneal epithelium. J Anat 1950, 84: $50-6$.

${ }^{4}$ Tseng SCG, Hatchell D, Tierney N, Huang AJW, Sun TT: Expression of specific keratin markers by rabbit corneal, conjunctival, and esophageal epi- thelial during vitamin A deficiency. J Cell Biol 1984, 99: 2279-86.

${ }^{45}$ Huang AJW, Tseng SCG, Kenyon KR: Paracellular permeability of corneal and conjunctival epithelia. Invest Ophthalmol Vis Sci (Submitted, 1988).

${ }^{46}$ Mishima S, Hedbys BO: The permeability of the corneal epithelium and endothelium to water. Exp Eye Res 1967, 6: 10-32.

${ }^{47}$ Hanna C and O'Brien JE: Cell production and migration in the epithelial layer of the cornea. Arch Ophthalmol 1960, 64: 536-9.

${ }^{48}$ Moses RA, Parkinson G, Schuchardt R: A standard large wound of the corneal epithelium in the rabbit. Invest Ophthalmol Vis Sci 1979, 18: 103-6.

${ }^{49}$ Ubels JL, Edelhauser HF, Austin KH: A comparison of healing of corneal epithelial wounds stained with fluorescein or Richardson's stain. Invest Ophthalmol Vis Sci 1982, 23: 127-31.

${ }^{50}$ Matsuda M, Ubels JL, Edelhauser HF: A larger corneal epithelial wound closes at a faster rate. Invest Ophthalmol Vis Sci 1985, 26: 897-900.

51 Jumblatt MM and Neufeld AH: A tissue culture assay of corneal epithelial wound closure. Invest Ophthalmol Vis Sci 1986, 27: 8-13.

52 Friedenwald JS and Buschke W: So me factors concerned in the mitotic and wound-healing activities of the corneal epithelium: Trans Am Ophthalmol Soc 1944, 42: 371-83.

${ }^{53}$ Kuwabara T, Perkins DG, Cogan DG: Sliding of the epithelium in experimental corneal wounds. Invest Ophthalmol Vis Sci 1976, 15: 4-14.

${ }^{54}$ Buck RC: Cell migration in repair of mouse corneal epithelium. Invest Ophthalmol Vis Sci 1979, 18: 767-84.

${ }^{55}$ Davanger $\mathbf{M}$ and Evensen $\mathrm{A}$ : Role of the pericorneal papillary structure in renewal of corneal epithelium. Nature 1971, 229: 560-1.

56 Pizzarello LD and Jakobiec FA: Bowen's disease of conjunctiva: a misnomer. In: Ocular and Adnexal Tumors, Jakobiec FA (ED). Birmingham, Aeculapius: 1978; pp. 553-71.

57 Waring GO, III, Roth AM, Ekins MB: Clinical and pathologic description of 17 cases of corneal intraepithelial neoplasia. Am J Ophthalmol 1984, 97: 547-59.

${ }^{58}$ Ebato B, Friend J, Thoft RA: Comparison of central and peripheral human corneal epithelium in tissue culture. Invest Ophthalmol Vis Sci 1987, 28: $1450-6$.

${ }^{59}$ Srinivasan BD and Eakins KE: The reepithelialization of rabbit cornea following single and multiple denudation. Exp Eye Res 1979, 29: 595-600.

${ }^{60}$ Huang AJW and Tseng SCG: Corneal wound healing in the absence of limbal epithelium. ARVO Abstracts. Invest Ophthalmol Vis Sci 1988, 29: (Suppl): 190.

${ }^{61}$ Kinoshita S, Friend J, Thoft RA: Sex chromatin of donor corneal epithelium in rabbits. Invest Ophthalmol Vis Sci 1981, 21: $434-41$.

${ }^{62}$ Kaye DB: Epithelial response in penetrating keratoplasty. Am J Ophthalmol 1980, 89: 381-7.

${ }^{63}$ Alldredge OC and Krachmer JH: Clinical types of 
corneal transplant rejection; their manifestations, frequency, preoperative correlates, and treatment. Arch Ophthalmol 1981, 99: 599-604.

${ }^{64}$ Buck RC: Measurement of centripetal migration of normal corneal epithelial cells in the mouse. Invest Ophthalmol Vis Sci 1985, 26: 1296-9.

${ }^{65}$ Thoft RA and Friend J: The X, Y, Z hypothesis of corneal epithelial maintenance. Invest Ophthalmol Vis Sci 1983, 24: 1442-3.

${ }^{66}$ Schermer A, Galvin S, Sun TT: Differentiationrelated expression of a major $64 \mathrm{~K}$ corneal keratin in vivo and in culture suggests limbal location of corneal epithelial stem cells. J Cell Biol 1986, 103: 49-62.

${ }^{67}$ Cotsarelis G, Dong G, Sun TT, Lavker RW: Differential response of limbal and corneal epithelia to phorbol myristate acetate (TPA). ARVO Abstracts. Invest Ophthalmol Vis Sci 1987, 28 (Suppl): 1 .

${ }^{68}$ Lavker RM, Dong G, Cotsarelis G, Sun TT: Limbal basal epithelial cells display characteristics consistent with stem cells from various stratifying epithelia. Invest Ophthalmol Vis Sci, 1988, 29 (Suppl): 191.

${ }^{69}$ Kinoshita S, Kiorpes TC, Friend J, Thoft RA: Limbal epithelium in ocular surface wound healing. Invest Ophthalmol Vis Sci 1982, 23: 73-80.

${ }^{70}$ Kinoshita S, Friend J, Kiorpes TC, Thoft RA: Keratin-like proteins in corneal and conjunctival epithelium are different. Invest Ophthalmol Vis Sci 1983, 24: 577-81.

${ }^{71}$ Greiner JV, Covington HI, Allansmith MR: The human limbus. A scanning electron microscopic study. Arch Ophthalmol 1979, 97, 1159-65.

72 Vogt A: Atlas of the Slitlamp-Microscopy of the Living Eye; Technic and Methods of Examination. Berlin: Springer, 1921.

${ }^{73}$ Bron AJ and Goldberg MF: Clinical features of human limbus. In: The Cornea in Health and Disease; VIth Congress of the European Society of Ophthalmology, Trevor-Roper PD (ed). London: Academic Press, 1981, pp. 15-20.

${ }^{74}$ Goldberg MF and Bron AJ: Limbal palisades of Vogt. Trans Am Ophthalmol Soc 1982, 80: 15571.

${ }^{75}$ Maumenee AE: Repair in cornea. Adv Biol Skin 1964, 5: 208-15.

${ }^{76}$ Srinivasan BD, Worgul BV, Iwamoto T, Eakins $\mathrm{KE}$ : The reepithelialization of rabbit cornea following partial and complete epithelial denudation. Exp Eye Res 1977, 25: 343-51.

${ }^{77}$ Friedenwald JS: Growth pressure and metaplasia of conjunctival and corneal epithelium. Doc Ophthalmol 1951, 5-6: 184-92.

${ }^{78}$ Shapiro MS, Friend J, Thoft RA: Corneal re-epithelialization from the conjunctiva. Invest Ophthalmol Vis Sci 1981, 21: 135-42.

${ }^{79}$ Tseng SCG, Hirst LW, Farazdaghi M, Green WR: Goblet cell density and vascularization during conjunctival transdifferentiation. Invest Ophthalmol Vis Sci 1984, 25: 1168-76.

${ }^{80}$ Thoft RA and Friend J: Biochemical transforma- tion of regenerating ocular surface epithelium. Invest Ophthalmol Vis Sci 1977, 16: 14-20.

${ }^{81}$ Friend $\mathbf{J}$ and Thoft RA: Functional competence of regenerating ocular surface epithelium. Invest Ophthalmol Vis Sci 1978, 17: 134-9.

82 Thoft RA, Friend J, Murphy HS: Ocular surface epithelium and corneal vascularization in rabbits. I. The role of wounding. Invest Ophthalmol Vis Sci 1979, 18: 85-92.

${ }^{83}$ Kinoshita S, Friend J, Thoft RA: Biphasic cell proliferation in transdifferentiation of conjunctival to corneal epithelium in rabbits. Invest Ophthalmol Vis Sci 1983, 24: 1008-14.

${ }^{84}$ Liu SH, Tagawa Y, Prendergast RA, Franklin RM, Silverstein AM: Secretory component of $\operatorname{IgA}$ : A marker for differentiation of ocular epithelium. Invest Ophthalmol Vis Sci 1981, 20: 100-9.

${ }^{85}$ Harris TM, Berry ER, Pakurar AS, Sheppard LB: Biochemical transformation of bulbar conjunctiva into corneal epithelium: An electrophoretic analysis. Exp Eye Res 1985, 41: 597605.

${ }^{86}$ Tseng SCG, Hirst LW, Farazdaghi M, Green WR: Inhibition of conjunctival transdifferentiation by topical retinoids. Invest Ophthalmol Vis Sci 1987, 28: $538-42$.

${ }^{87}$ Tseng SCG, Farazdaghi M, Rider AA: Conjunctival transdifferentiation induced by systemic vitamin A deficiency in vascularized rabbit corneas. Invest Ophthalmol Vis Sci 1987, 28: $1497-$ 504.

${ }^{88}$ Tseng SCG and Farazdaghi M: Reversal of conjunctival transdifferentiation by topical tretinoin. Cornea, (1988 in press).

${ }^{89}$ Huang AJW, Tseng SCG, Farazdaghi M, Kenyon KR: Modulation of paracellular permeability during corneal epithelial wound healing. ARVO Abstracts. Invest Ophthalmol Vis Sci 1986, 27 (Suppl): 54.

${ }^{90}$ Huang AJW, Watson BD, Hernandez E, Tseng SCG: Induction of conjunctival transdifferentiation on vascularized corneas by photothrombotic occlusion of corneal vascularization. Ophthalmology 1988, 95: 228-35.

${ }^{91}$ Van Horn DL, Schutten WH, Hyndiuk RA, Kurz P: Xerophthalmia in vitamin A-deficient rabbits; clinical and ultrastructural alterations in the cornea. Invest Ophthalmol Vis Sci 1980, 19: 1067-79.

${ }^{92}$ Cintron C, Hassinger L, Kublin CL, Friend J: A simple method for the removal of rabbit corneal epithelium utilizing n-heptanol. Ophthalmic Res 1979, 11: 90-6.

${ }_{93}$ Maumenee AE, Scholz RO, III: The histopathology of the ocular lesions produced by the sulfur and nitrogen mustards. Bull Johns Hopkins Hosp 1948, 82: $121-47$.

${ }^{94}$ Tseng SCG: Staging of conjunctival squamous metaplasia by impression cytology. Ophthalmology 1985, 92: 728-33.

95 Tseng SCG: Application of corneal impression cytology to study conjunctival transdifferentiation defect. In the proceedings of the First International Symposium on Ophthalmic Cytology. 
Parma, Italy, 1988, Ed Orson JA Centro Grafico Editoriale, Universita Degli Studi Parma. pp 6576.

${ }^{96}$ Hughes WF, Jr: Alkali burns of the eye. I. Review of the literature and summary of present knowledge. Arch Ophthalmol 1946, 35: 423-49.

${ }^{97}$ Hughes WF, Jr: Alkali burns of the eye. II. Clinical and pathologic course. Arch Ophthalmol 1946. 36: $189-214$.

${ }^{98}$ Mackman G, Brightbill FS, Optiz JM: Corneal changes in aniridia. Am J Ophthalmol 1979, 87: 497-502.

${ }^{99}$ Margo CE: Congenital aniridia: a histopathologic study of the anterior segment in children. J Ped Ophthalmol Strabismus 1983, 20: 192-8.

${ }^{1(*)}$ Nelson LB, Spaeth GL, Nowinski T, Margo CE, Jackson L: Aniridia. A review. Surv Ophthalmol 1984, 28: 621-42.

${ }^{101}$ Frati L, Daniele S, Delogu A, Covelli I: Selective Binding of epidermal growth factor and its specific effects on the epithelial cells of the cornea. Exp Eye Res 1972, 14: 135-141.

102 Ho PC, Davis WH, Elliott JH, Cohen S: Kinetics of corneal epithelial regeneration and epidermal growth factor. Invest Ophthalmol 1974, 13: 804-9.

${ }^{103}$ Petroutsos G, Courty J, Guimaraes R. Pouliquen Y, Barritault D, Plouet J, Courtois Y: Comparison of the effects of EGF, pFGF, and EDGF on corneal epithelium wound healing. Curr Eye Res 1984, 3: 593-8.

${ }^{104}$ Fredj-Reygrobellet D, Plouet J, Delayre T. Baudouin C, Bourret F. Lapalus P: Effects of aFGF and bFGF on wound healing in rabbit corneas. Curr Eye Res 1987, 6: 1205-9.

${ }^{105}$ Singh G and Foster CS: Epidermal growth factor in alkali-burned corneal epithelial wound healing. Am J Ophthalmol 1987, 103: 802-7.

${ }^{106}$ Nishida T, Nakagawa S. Nishibayashi C, Tanaka H. Manabe R: Fibronectin enhancement of corneal epithelial wound healing of rabbits in vivo. Arch Ophthalmol 1984, 102: 455-6.
${ }^{107}$ Allam B and Insler MS: The use of fibronectin in the healing of persistent epithelial defects in the rabbit cornea. J Ocular Ther Surg 1985, 4: 89-92.

108 Phan T-MM, Foster CS, Boruchoff SA, Zagachin LM, Colvin RB: Topical fibronectin in the treatment of persistent corneal epithelial defects and trophic ulcers. Am J Ophthalmol 1987, 104: 494501 .

${ }^{109}$ Alaniz-Camino F: The use of post-operative beta radiation in the treatment of pterygia. Ophthalmic Surg 1982, 13: 1022-5.

"1" Monselise M, Schwartz M, Politi F, Barishak YR: Pterygium and Beta irradiation. Acta Ophthalmol 1984, 62: 315-19.

III Aswad Ml and Baum J: Optimal time for postoperative irradiation of pterygia. Ophthalmology 1987, 94: 1450-51.

112 Gourcuff A, Tassy A, Garron J, Perruchot P-J, Blondel P: Thio-tepa en collyre pour les recidives de pterygion et de neo-vascularisation de cornee. Bull Soc Ophthal less \# Fr 1984, 84: 583-7.

113 Vorkas AP: Pterygium. Choice of operation. Trans Ophthalmol Soc UK 1981, 101: 192-4.

${ }^{11+}$ Kenyon KR, Wagoner MD, Hettinger ME: Conjunctival autograft transplantation for advanced and recurrent pterygium. Ophthalmology 1985 , 92: 1461-70.

${ }^{115}$ Rivaud C, Vingtain P, Cozette P, Ginoux J, Menerath JM: Techniques et resultats des autogreffes dans la chirurgie du pterygion. Etude portant sur 34 greffes. J Fr Ophthalmol 1986, 9: 217-225.

116 Thoft RA: Conjunctival transplantation. Arch Ophthalmol 1977, 95: 1425-7.

117 Thoft RA: Conjunctival transplantation as an alternative to keratoplasty. Ophthalmology 1979, 86: 1084-91

${ }^{118}$ Huang AJW and Tseng SCG: Development of monoclonal antibodies to rabbit ocular mucin. Invest Ophthalmol Vis Sci 1987. 28: 1483-91.

${ }^{119}$ Kenyon KR and Tseng SCG: Limbal autograft transplantation for ocular surface disorders. $O p h$ thalmology 1989, 96 (In Press). 